\title{
O Jesus marginal de Chico Buarque e Renato Russo
}

\author{
Fabrício Dantas
}

FERRAZ, S., et al.,orgs. Deuses em poéticas: estudos de literatura e teologia [online]. Belém: UEPA; Campina Grande: EDUEPB, 2008. 364 p. ISBN 978-85-7879-010-3. Available from SciELO Books $<\underline{\text { http://books.scielo.org }>\text {. }}$

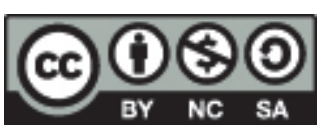

All the contents of this work, except where otherwise noted, is licensed under a Creative Commons Attribution-Non Commercial-ShareAlike 3.0 Unported.

Todo o conteúdo deste trabalho, exceto quando houver ressalva, é publicado sob a licença Creative Commons Atribuição Uso Não Comercial - Partilha nos Mesmos Termos 3.0 Não adaptada.

Todo el contenido de esta obra, excepto donde se indique lo contrario, está bajo licencia de la licencia Creative Commons Reconocimento-NoComercial-CompartirIgual 3.0 Unported. 


\section{O Jesus Marginal de Chico Buarque e Renato Russo}

Fabrício Dantas 


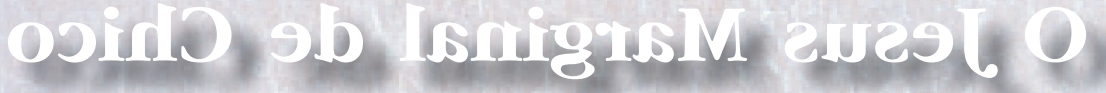

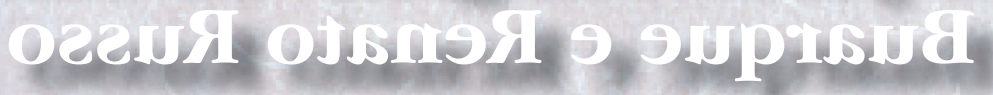

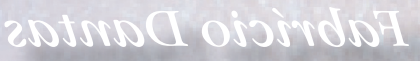


Resumo: Considerando os estudos convergindo literatura e teologia, linguagens tais que resgataram a "condição humana, em sua espessura material e densidade simbólica" (Barcellos, 2001), visamos confluir a Teologia da libertação, que articulou o lugar da fé e da existência ao lugar da realidade social (Boff, 1984), com a construção simbólica de Cristo como sujeito marginalizado nas canções Faroeste Caboclo (1979) de Renato Russo, da banda Legião Urbana, e Minba bistória, adaptação de Chico Buarque da canção italiana Gesùbambino (1971), de L. Dalla e Pallottino. Selecionamos os textos por apresentarem forte empreendimento teológico ao ressemantizarem a imagem de Jesus Cristo salvador como anti-herói, vilão e vítima da e na própria história. Basearemos nossa análise em princípios relacionados ao perfil de Cristo, previstos pela teologia da libertação, bem como nos deteremos à confluência entre o papel da arte e da teologia na chamada era da pósmodernidade.

Palavras-chave: Renato Russo, Chico Buarque, Teologia e literatura, Teologia da libertação, Visão de Jesus

Abstract: Considering studies that converge Literature and Theology with languages that rescued the "human condition in its material thickness and symbolic density" (Barcellos, 2001), the articles seeks to converge the Theology of Liberation - which articulated the place of faith and existence with the place of social reality (Boff, 1984) - to two wellknown works of Brazilian popular music. More specifically, it seeks to explore the symbolic construction of Christ as a marginalized subject in the 1979 Faroeste Caboclo (composed by Renato Russo, lead of the band Legião Urbana) and the 1971 Minha História (an adaptation by Chico Buarque of the Italian song Gesùbambino, by L. Dalla and Pallottino). The two texts were selected due to the fact that both evidence a strong theological investment even as they recast the salvific Jesus

\footnotetext{
* Licenciado em Letras Vernáculo pela Universidade Federal de Campina Grande, (UFCG) e Mestrando em Literatura e Interculturalidade (MLI) na Universidade Estadual da Paraíba (UEPB) com a orientação do Prof. Dr. Eli Brandão da Silva. Atua na Linha de Pesquisa 'Espiritualidade, religião e pensamento teológico na Literatura' e é membro do grupo de pesquisa 'Litterasofia. Hermenêutica literária em diálogo com a filosofia e a teologia'. E-mail: fabricio19@hotmail.com
} 
Christ as an anti-hero, a villain and a victim of and in history. We base our analysis on principles related to the profile of Christ as described by the Theology of Liberation, and address the confluent roles of art and theology in the so-called postmodern age.

Keywords: Renato Russo, Chico Buarque, Theology and literature, Theology of Liberation, Vision of Jesus 


\section{A utopia da utopia: (re)visando a este conceito no contexto latino-americano}

Declara o artigo primeiro da Declaração Universal dos Direitos Humanos, de 1948: "Todos os seres humanos nascem livres e iguais em dignidade e direitos e, dotados como estão de razão e consciência, devem comportar-se fraternalmente entre si”. Parece razoavelmente estranha esta assertiva, quando olhamos para um passado não muito distante de nosso país e da América Latina, em que predominavam as guerras e as ditaduras. E estranho também é perceber que após 60 anos em que a Assembléia Geral da ONU (Organização das Nações Unidas) proclamou aquela Declaração, ainda existam tantas pessoas que se sentem presas, violentadas, guerreando ou sobrevivendo em condições indignas. Após a $2^{\mathrm{a}}$ Guerra Mundial, o que será que mudou de lá para cá? O que se garantiu, de fato, após as guerras? E antes delas para hoje em dia, será que predominaram os saldos positivos das mudanças geradas desde então?

O fato é que para onde olharmos vemos injustiças, condições degradantes de vida, corrupção, desigualdades sociais. O contexto da América Latina é um bom exemplo disso. Desde o que se entende como a formação do continente americano, percebe-se uma tendência à submissão e exploração ou prevalência e hegemonia do poderio dos ricos oprimindo os pobres.

Os países que compõem a América Latina sempre presenciaram em sua história, experiências desalentadoras como as ditaduras e administrações desastrosas que geraram, dentre outros problemas, fracassos na área social e na aplicação dos recursos. No que diz respeito à construção de uma identidade para a América Latina, percebe-se, desde sua gênese, a busca de uma utopia freqüente. Se na época da colonização o Novo Mundo foi visto como a redenção para a humanidade, um éden, um paraíso mítico onde poderia haver um novo começo para aquelas sociedades européias em crise financeira e sanitária, no período que correspondeu à busca das independências das nações latino-americanas até a atualidade, as utopias vêm ou vinham sendo constituídas, reformuladas, renovadas. Na verdade, como nos atesta Jung Mo Sung no livro Sujeitos e sociedades complexas: para repensar os borizontes utópicos, "sonhar e ter esperanças são necessidades vitais quase tanto quanto comer e beber, pois somos seres biológicos e simbólicos e precisamos encontrar um sentido e uma razão para vivermos". (Sung, 
2002, p.9)

Mas, de fato, o que significa "Utopia"? Segundo Brito \& Freire (1987:84), no texto Utopia e paixão: a política do cotidiano, aquele termo foi proposto no século XVI, quando o inglês Thomas Morus publicou em latim um livro sobre uma vida melhor levada pelos habitantes de uma ilha situada em algum lugar, a ilha de Utopia, isto é, o não-lugar ou lugar nenhum. Segundo os mesmos autores, isso se deveu ao fato de que na Inglaterra de Morus não existia liberdade de expressão e nem de pensamento, daí a fabricação de uma palavra para situar um lugar onde a vida seria melhor. Neste raciocínio, a utopia se insere numa busca que visa refazer um mundo novo, no campo do sonho, da ficção, da imaginação que poderá um dia tornar-se topos.

A conclusão a que se chega, portanto, é a de que toda construção de sociedade passa pela utopia, que acaba por ser combustível capaz de gerar uma possível revolução social. Enfim, como nos diz Rossi (1999) em sua tese de doutorado intitulada Horizontes utópicos e projetos bistóricos - a centralidade religiosa do messianismo no ordenamento do mundo moderno, "a utopia é uma necessidade epistemológica para todos aqueles que desejam intervir na sociedade. Sem a utopia, o conhecimento social da realidade fica restrito ao existente, impedindo o traçar de estratégias para a transformação da realidade". (op.cit, p.120)

No momento atual, apesar do fim das ditaduras e de ter-se chegado a uma realidade mais democrática, faz-se oportuno revisitar o sentido da utopia, principalmente porque observamos um predomínio, um egocentrismo ou crise ética na sociedade, além de forte ilusão e desesperança espalhando-se de maneira sistemática.

Destarte, subsiste na América Latina uma imperiosa contradição: de um lado, constatamos intensa modernidade, enriquecimento rápido de poucos indivíduos detentores dos modos de produção, muitas vezes se corrompendo e utilizando meios ilícitos para manter-se no poder; do outro, visualizamos grandes parcelas da sociedade sofrendo com as mazelas geradas pela corrupção e descaso de políticos, muitas vezes em países que dispõem de recursos naturais exuberantes, o que, em princípio, poderia garantir uma real eqüidade entre os cidadãos.

Tal modelo, denominado neoliberalismo, baseado no consumismo e no demasiado lucro, vem tendo como maior conseqüência a exclusão social e, por extensão, vem reforçando o ethos fundamentado no individualismo. Ou seja, as pessoas cada vez mais, ou por necessi- 
dades econômicas de subsistência, ou pelo aumento da violência, da marginalização; ou ainda pelo cotidiano urbano bastante acelerado, vêm sentindo dificuldade de serem inseridas no mercado ou favorecidas pelas benesses das promessas do capitalismo. Daí decorre a fragilização de utopias, a exemplo do socialismo utópico, uma vez que já não se acredita que seja possível alguma mudança sócio-histórica concreta. (Rossi, op.cit., p.118),

Não obstante, no que diz respeito à reconfiguração dos anseios coletivos, duas expressões culturais vêm desempenhado notáveis expressões teológicas e sensibilidades utópicas, ao mesmo tempo. Tratamos da Teologia da Libertação e dos movimentos lítero-musicais, que tentaremos observar de que modo podem ser confluídos no contexto latino-americano contemporâneo.

\section{A Teologia da Libertação e seu alcance utópico}

A Teologia da Libertação (TL) surgiu como uma visão diferenciada do Cristianismo que, sobretudo a partir da década de 1960 agiu, age ou deixou marcas que garantiram novos horizontes para o oprimido latino-americano. Desta forma, a TL nasceu

da indignação ética frente a situações em que os seres humanos são reduzidos à condição subumana. Indignação ética, forte suficiente para levar as pessoas a assumirem riscos e dores de outros/as, que era percebida como uma experiência espiritual, a de encontrar a pessoa de Jesus Cristo no rosto das pessoas esmagadas e oprimidas. (Sung, 2002, p. 44, negrito nosso)

Neste sentido, entende-se que todo pensamento ou projeto utópico é uma manifestação política, uma proposta idealista de organização social mais justa, precisamente o que seria o maior respaldo da Teologia da Libertação que, como sabemos, baseou-se na figura história de Jesus Cristo para se concretizar. (Brito \& Freire, 1987, p.85). Outrossim, a chamada Teologia da libertação, na acepção de Jon Sobrino (1996), em seu livro A história de Jesus de Nazaré, é eminentemente contextual, uma vez que não se limita a realidades concretas e/ou plenamente misteriosas, mas busca sempre o fim da opressão e dignidade para os pobres. Contudo, para ter se aplicado os princípios teológicos libertários teve-se que distinguir o Cristo como Salvador-libertador, no 
sentido da fé naquele que Salvou o mundo, do Cristo Crucificado, fruto de sua história de forma emblemática capaz de ter gerado uma tradição teológica baseada no princípio máximo da ressurreição. (Sobrino, 1996)

Neste raciocínio, considerando principalmente o Cristo Libertador, o cristianismo mais contemporaneamente acabou tendo que se "aperfeiçoar" devido a razões históricas no contexto latino-americano. Ou seja, necessitou-se um Cristo aliado da libertação. E a Utopia cristã maior seria, segundo Sobrino, a libertação integral do indivíduo de modo a concretizar o reino de Deus, ou seja, os seres humanos viverem em paz, de forma digna como realmente humanos.

Em tal acepção de Cristo, o fundamental é optar-se pelos pobres, em sua misericórdia e justiça, e na sua confrontação com os poderosos, bem como na perseguição e morte por causa disso, além de sua ressurreição reivindicadora. Enfim, um Jesus presente, ao mesmo tempo, como elemento de fé, personagem histórico, ao configurar-se como lugar de atuação do ser humano, de inserção política e religiosa, além de funcionar como símbolo sócio-cultural.

Esta visão tão plural de Jesus Cristo é cada vez mais observada pelos estudiosos da teologia contemporânea e por críticos culturais de influência teológica que vêm observando como se vem transfigurando a imagem de Jesus em obras literárias, teatrais, musicais, artísticas, enfim. Como exemplo, podemos contemplar o que nos diz o imortal Segundo Sérgio Corrêa da Costa em seu „Discurso de Posse“ na Academia Brasileira de Letras em 2006, como registra o site oficial daquele órgão, isto é, http://www.academia.org.br.

Para ele, na medida em que os preconceitos religiosos se foram atenuando, os escritores do século XX começaram a dar tratamento literário à figura de Jesus, com crescente desembaraço. Os Evangelhos começaram a ser encarados como parte de um patrimônio cultural, e não somente artigos de fé. No transcorrer do raciocínio em que trata da abordagem de Jesus na arte, o mesmo escritor ainda cita algumas categorias envolvendo o drama de Jesus construídas por Theodore Ziolkowski, professor de literatura comparada em Princeton, no texto Fictional transfigurations of Jesus (1978). Seriam cinco as categorias: (1) as "transfigurações"; (2) as biografias ficionalizadas. (3) Jesus redivivus; (4) a Imitatio Christi e (5) os "pseudônimos" de Cristo. O tema das "transfigurações" identificaria aquele herói moderno cuja vida foi meramente "prefigurada" por Jesus. Nas "biografias ficcionalizadas", a 
peça capital é o próprio Jesus histórico. Dentre tais categorias enfatiza Costa sobretudo as duas últimas: a "Imitatio Christi" vista como aquela que abrange as obras em que o herói se propõe a viver tal como Jesus, se nascido em nosso meio; ou seja, seria um herói moderno que age segundo sua própria concepção de Cristo; enquanto que na quinta e última categoria - a dos "pseudônimos de Cristo" - subsistiria qualquer ficção desde que o herói tenha semelhança perceptível com Jesus.

Sem querermos discutir as várias possibilidades de apreciação e estilização da figura de Jesus na arte, sobretudo literária, com este adendo queríamos apenas ratificar a pertinência do se observar a figuração de Jesus na arte até mesmo dedicando discussões acerca da evolução dos paradigmas também teológicos como o caso da Teologia da Libertação que, sem dúvida, foi e é uma das visões mais inovadoras do papel de Jesus e de sua missão no momento atual.

Voltando à discussão mais precisa sobre a Teologia da Libertação lembramos o que o importante teórico Echegaray (1991) disse em seu capítulo $\mathrm{O}$ projeto de Jesus do livro A prática de Jesus. Neste texto, revela-nos aquele autor aspectos interessantes acerca da classe social de Jesus, elementos tais que identificam Jesus como convergente com as classes pobres (ou empobrecidos injustamente) a serem transformados pela Teologia da Libertação, algo bem extenso e heterogêneo, abrangendo desde os excluídos do poder, de riqueza e privilégios, até os analfabetos considerados ignorados em matéria religiosa.

Neste sentido, então, nada mais natural do que a Teologia da Libertação incluir os muitos rostos da opressão, como as crianças, os jovens, os camponeses, operários, subempregados e desempregados, marginalizados e os anciãos, além dos pobres sócio-econômicos, dos oprimidos física e espiritualmente - o submetido, o discriminado - e dos oprimidos em virtude da raça (o negro), da etnia (o índio), ou do sexo (a mulher).

Basicamente, seguindo este raciocínio, a Teologia da Libertação estaria nada mais fazendo senão redescobrir aquilo que era a vocação perene de toda uma leitura bíblica eficaz, que visa coadunar-se com a contemporaneidade dos fatos. Uns dos livros da Bíblia que se destacam nesse sentido são os chamados Evangelhos sinópticos, como os de Mateus e Lucas. Tais escritos, ao centrarem-se na pessoa divina de Jesus, sua mensagem do Reino, crítica libertadora, sua morte e ressurreição, tornam-se veículos ilustradores da "marginalização" a que se deixou submeter Jesus, por ter sido revolucionário, ao ter anunciado 
as boas aventuranças (Mt 5: Felizes pobres de coração; Felizes os perseguidos por causa da justiça), ter-se aproximado dos pecadores (Mt 9 -Jesus chama Mateus), ter rompido com as leis judaicas da época (Mt 12 - As espigas arrancadas), e ter dado relevado classes ou faixas sociais antes desconsideradas como as crianças (Mt 19 - Jesus e as crianças) e os pobres, quando trata da obrigação de renúncia à riqueza material (Lc 12, 14 e 18).

Enfim, a libertação está especialmente ligada à busca de justiça social, ao desafio contra as várias formas de opressão presente nos evangelhos, bem como o renascimento de Jesus, através dos movimentos de protesto e de contestação social. O fator religioso, no caso da Teologia da Libertação, é utilizado neste raciocínio, como elemento de projeção para uma nova realidade, em que haja mais participação, mais justiça e democracia, de modo a conscientizar interessados proféticos, libertários e comprometidos com mudanças sociais necessárias. Tudo isto "para superar a herança de exclusão histórica que estigmatiza a vida do povo." (Echegaray, 1991, p.194)

\section{O Pobre negro e o Negro pobre em questão: alcances e/ou preferências da Teologia da Libertação}

Juntamente com o elemento "pobre" ou empobrecido injustamente, como vimos, imprimiram-se novas nuances como elementos étnicos e sexuais para o arcabouço da Libertação. $O$ caso do negro é um forte exemplo disso. A chamada "Teologia do Negro" já admitiu grande expansão e aqui trataremos de modo breve por tangenciar a perspectiva de nosso trabalho.

No livro O Deus dos oprimidos, James Cone entende que a forma como se vê Jesus Cristo hoje se transformou sensivelmente. Já não procede entender Jesus Cristo como uma simples verdade da história cristã. Ou seja, não conviria mais que os cristãos contemporâneos repetissem a história daquilo que Jesus fez e disse na Palestina, como se isso tivesse uma auto-interpretação para nós, hoje. Há que, sem dúvida, "olhar para a nossa situação atual, revelando o significado do passado para o presente, a fim de que nós nos tornemos novas criaturas para o futuro". (Cone, 1985, p.120)

Seguindo este raciocínio é que o citado autor afirma a negritude de Jesus Cristo, entendendo-a tanto literal como simbólica. Literal porque verdadeiramente se solidarizou com os negros oprimidos, to- 
mando o sofrimento destes como o seu sofrimento e revelando que ele é encontrado na história da luta dos homens, na história de sua cor e no ritmo de seus corpos. E simbolicamente significa dizer que o povo negro é o pobre de Deus a quem Cristo veio libertar. Em outras palavras, dizer que Cristo é negro significa que Deus, em sua sabedoria e misericórdia infinitas, não apenas leva a cor seriamente, mas a toma sobre si e revela sua vontade de fazer de todos os seres humanos novas criaturas nascidas no espírito da negritude divina e redimidas através do sangue do Cristo Negro. Enfim,

Cristo é negro não por causa de alguma necessidade cultural ou psicológica do povo negro, mas por causa e somente porque Cristo realmente entra em nosso mundo, onde os pobres, os desprezados e os negros estão revelando que está com eles, sofrendo a humilhação e a dor deles e transformando os escravos oprimidos em servos libertados. (Cone, 1985, p.150)

Ainda acerca do quesito pobreza, vale lembrar o que Leonardo Boff (1986) explica em Do lugar do pobre. Neste livro, entende Boff que a preferência pelo pobre diz respeito à luta pela injustiça social. Na verdade, quando se fala em pobres, na expansão "opção preferencial pelos pobres", deve-se entender pobreza no sentido que Puebla lhe confere, isto é, uma concepção mais genérica. (Boff, 1986).

Isto porque a realidade da pobreza é considerada como "o mais devastador e humilhante flagelo"; "não uma etapa causal, mas o produto de determinadas situações e estruturas econômicas, sociais e políticas". Afinal, pobre possui um sentido histórico concreto e não apenas metafórico e espiritual, mas um sentido real. Daí o porquê de "a opção da Igreja pelos pobres significar uma opção pelos injustamente feitos pobres, portanto empobrecidos". (Boff, op.cit, p.54)

Portanto, seja enfocado o pobre, seja enfocando o negro, elementos tangenciados e enfocados nos textos aqui a serem trabalhados, o que se busca não é "prestigiar" alguma etnia ou classe per si, mas fazer as justas adequações e recuperar o que em geral sofreu mais ao longo da história latino-americana. 


\section{Jesus marginal como elemento teológico da liberta- ção: aproximações entre Chico Buarque e Renato Rus- SO}

A Teologia da Libertação foi capaz de gerar similitudes, conscientes ou não, com a arte lítero-musical brasileira a partir do momento que trouxe à baila reflexões sobre o papel de Jesus na contemporaneidade, trazendo-o a uma realidade mais concreta. É o que tentaremos verificar a partir de dois compositores e intérpretes até hoje bem populares que, cada um a seu estilo, conseguiram de forma poética e emblemática coadunar sua obra com a visão do perfil do pobre enfatizado pela busca da libertação. Tratamos dos autores Chico Buarque, com a canção Minha bistória, de 1970, releitura da canção Gesùbambino dos italianos Lúcio Dalla e Paola Palotino, e Renato Russo, líder da extinta Legião Urbana, com a já bastante conhecida música Faroeste Caboclo.

Ambos artistas conseguiram traduzir em letras profundas, algumas aspirações, dúvidas, angústias, e sonhos e/ou utopias de gerações de jovens brasileiros no contexto da ditadura e do pós-ditadura.

\subsection{A libertação em Minha História}

Francisco Buarque de Holanda, conhecido como Chico Buarque é músico, cantor, compositor, teatrólogo e escritor brasileiro que, há mais de quarenta anos, vêm cativando o público com as suas produções musicais e literárias. Produziu bastante desde a época dos Festivais de Música Popular Brasileira, patrocinados pela TV Record, momento em que o Regime Militar no Brasil imperava no Brasil, sobretudo até o fim da década de 80 . Boa parte de sua obra apresenta um engajamento devido aos males gerados pela ditadura no Brasil. Tanto é que, em 1969, chegou a ser exilado na Itália, época em que teve algumas de suas canções como Apesar de você (alusão negativa ao presidente Emílio Garrastazu Médici) e Cálice "barradas" pela censura brasileira. E na Itália foi onde justamente Chico tornou-se amigo do cantor Lucio Dalla, a partir de quem fez a bela canção Minba História, objeto de estudo nosso.

Assim como a Teologia da Libertação, parte do contexto que se vive para poder atuar, também podemos ver o contexto da canção Minba História, de Chico Buarque. A versão italiana, Gesùbambino, 
conquistou o terceiro lugar no Festival de San Remo, no ano de 1971, e neste mesmo ano foi transmitida para a televisão brasileira. Ou seja, era uma música que já estava em circulação e poderia ser ouvida nas rádios em sua versão original.

Contudo, assim como muitos teólogos da libertação sofreram opressão, restrições e foram martirizados, tal canção, na versão de língua portuguesa, também foi "martirizada" ao sofrer censura de cunho religioso e dos bons costumes, pelo regime ditatorial. Após a tentativa de lançamento público, o censor julgou que a obra era uma paródia grotesca com o uso indevido do nome Jesus Cristo.

$\mathrm{O}$ site www.censuramusical.com que se propõe a analisar os efeitos da censura na produção musical durante o regime militar, disponibiliza vários documentos que mostram como era feita a análise das canções então censuradas. E é onde justamente podemos nos deparar com o texto da censura frente à canção em pauta. $\mathrm{O}$ advogado de Chico Buarque naquela ocasião pediu a Chico Buarque que o mesmo explicasse a poesia da canção e o poeta escreveu o seguinte:

O texto conta a história da mulher que se apaixona, como tantas outras, por um aventureiro que parte, como tantos outros, e do filho que nasce sem pai, como tantos outros. O poema - é um poema - difere dos demais pela maneira singela como a autora aborda o problema da mãe solteira. Nada de abortos, de fugas, nada de entregar o filho a um orfanato ou deixá-lo à porta de uma Igreja. A mãe, desesperada, alucinada, "com o olhar cada dia mais longe", simplesmente dá ao filho o nome de Jesus. Um pouco por alucinação, mas também por ignorância. Um pouco por devoção, "por ironia ou por amor". E um pouco, entende-se, para se comparar à Virgem Maria e se isentar de qualquer pecado. Finalmente temos o filho feito homem, igual a todos os homens, pequeno como todos os mortais, fraco demais para carregar às costas $O$ nome de Jesus Cristo. E é só isso o poema.

Segundo o referido site, "apesar da análise precisa e do esforço das argumentações do advogado, a censura proibiu a música. E o censor fez a própria análise para decidir." Cita-se, assim, alguns trechos do parecer do censor, revelando uma espécie de martirização da arte poética uma que vez está carregado de preconceito, autoritarismo e 
limitação da compreensão da mensagem tanto cristã como poética da canção:

Trata-se de uma obra lítero-musical, cujo contexto resume-se a um relato feito por um filho espúrio (nominado Jesus Cristo pela mãe prostituta) sobre o romance efêmero de sua genitora com um desconhecido, responsável por sua vinda ao mundo (...)

Traduzida para o português, entretanto, a obra se nos apresenta como uma paródia grotesca, segundo meu juízo de valor, além de fazer uso indevido e em vão do nome de Cristo. (...)

Finalmente, o conteúdo deveras intelectivo da composição pode, mutatis mutandis, ser interpretado de maneira dúbia pela maioria do povo cristão, inapta a assimilar o alcance da mensagem nos termos propostos pelo tradutor. (...)

$\mathrm{Na}$ linha desse raciocínio, concluo pela não conveniência da liberação da obra para a finalidade requerida. $<$ http://portal.rpc.com.br/gazetadopovo/blog/sobretudo/?id=674790 > Acesso: maio de 2008

Agora observando o que nos diz o conteúdo da letra em si, vale observar o que nos aponta Maraschin (1974) no texto Jesus Cristo na música popular brasileira. Neste artigo, o citado autor aborda vários textos que têm como pano de fundo a imagem de Jesus Cristo sob várias perspectivas. Assim nos fala Maraschin em relação à música Minba História:

O "menino Jesus", secularizado e plenamente humanizador dessa canção, representaria, numa simbolização sofisticada, o comprometimento de Deus com os pobres e com os oprimidos. Fica implícita, nessa imagem, certa necessidade de desmitizar o sagrado. A estória da gravidez de Maria por obra do Espírito Santo é trazida para a crueza de um amor de marinheiro pela mulher infeliz do porto. (Maraschin, op.cit., 108).

Além de sugerir a abordagem crítico-libertária da perspectiva da canção, Maraschin também verifica a relação entre o personagem da canção "Menino Jesus" - homem comum que bebe, briga, com amantes 
e amigos - com o verdadeiro Jesus, como se fosse isso uma possível tentativa do poeta de dizer que o verdadeiro Jesus se reconhece tão plenamente humano como o eu-lírico do poema-canção. Ou seja, o Jesus real poderia ser aquele oprimido: aquele que sente fome, que está preso, que sofre desabrigado, e que é perseguido injustamente.

$O$ fato é que tal canção discute elementos bem concernentes à perspectiva de atuação da Teologia da Libertação. Primeiramente, observamos a ingenuidade de uma jovem ante um homem aventureiro, mais experiente, de aspecto malandro e apreciador do mar que acabara por conseguir a entrega da jovem, solitária, pobre, que acaba por engravidar. E também, como tantos perfis oprimidos na sociedade, por ser mulher jovem e pobre, apresenta certa religiosidade ou apreço religioso que a faz cuidar e nomear seu filho como Jesus. No entanto, pela mesma ingenuidade e falta de cultura, a jovem mãe acabara por ninar o filho com cantigas de cabaré, o que denota uma releitura um tanto polêmica da imagem divinal de Jesus Cristo, sobretudo para a época em que foi lançada a música, isto é, no contexto da ditadura.

$O$ fruto daquela conjunção entre o malandro e a jovem mulher, crescida também em meio boêmio não foi outro senão um oprimido a mais na sociedade: um sujeito marginal, "crucificado" como tanto "colegas de copo e cruz", nascido e crescido em meio boêmio e carecedor de formação edificante. Portanto, a correlação com a Teologia da Libertação advém da abordagem metafórico-crítica que reúne elementos da religiosidade cristã com aspectos sociais. Isto ocorre ao porque se reconhece a voz de um típico perfil desassistido que é o da mãe pobre solteira e um filho crescido sem pai, com poucos recursos e com tendências à marginalidade, tendo como círculo de amizades ladrões, beberrões e amantes, e grande prazer, a bebida alcoólica.

Observando o conteúdo da letra original em relação à versão brasileira, nota-se que houve mudanças bastante significativas em termos de adaptação, o que fortalece o já falado caráter crítico-libertário da versão brasileira. Uma primeira diferença diz respeito ao próprio título. A versão italiana Gesùbambino, que significa "Jesus Menino" teve que ser modificada no Brasil para Minha bistória também por influência da censura. Isto revela que, naquela época, o contexto italiano era bem mais favorável em termos de liberdade de expressão. Outro ponto forte reside no fato de que na adaptação Chico Buarque imprimiu um caráter mais crítico ao perfil do pai aventureiro. Enquanto na versão italiana o pai, que era um belo estrangeiro, fora assassinado, na versão 
de Chico, o pai demonstrara ser uma espécie de bon-vivant, que usava tatuagem, tinha "dourado no dente" e simplesmente abandonara a mulher que conquistara. Outra característica de diferenciação também relevante diz respeito àquele aspecto polêmico de que falamos. Isto é, em Minha História, a mãe, mesmo que apresente religiosidade ao nomear e cuidar do filho, o nina com canções de cabaré, o que sugere seu caráter marginal também presente no filho "Jesus", um indivíduo, como tantos outros, "crucificado" juntamente com colegas de copo, ladrões e amantes. Já na versão original suscita-se um caráter apenas boêmio do menino Jesus, que toma vinho e joga cartas.

\subsection{Utopia de salvação do Faroeste Caboclo}

Renato Russo, morto aos 36 anos por complicações decorrentes da Aids, mesmo tendo desaparecido da nossa ambiência física, permanece como chama de inconformismo e de rebeldia diante das melancolias e dos vazios que caracterizam o final do século XX. O líder do Legião Urbana constitui e constituirá uma sólida referência no quadro artístico-literário dos anos 80 e 90, por ter apresentado uma obra crítica, objetiva, polêmica e poética, ao mesmo tempo. Além disso, revelou uma utopia que recusava tanto os preconceitos e hipocrisias, como as desigualdades e as exclusões, e que previa um mundo mais justo entre as pessoas.

O surgimento de Renato Russo no cenário musical brasileiro deu-se em meados dos anos 80 , época na qual se situou a maior parte de sua produção musical. Também conseguiu potencializar em seu discurso muitos dos questionamentos de tantos jovens, motivados por inquietações existenciais, a ponto de terem ganhado dimensões bastante amplas.

Um dos aspectos mais comuns em sua obra é a propositura de mudança a ser realizada a partir da reestruturação do pensamento individual de tal modo que se possa, em progressão geométrica, evoluir e se efetivar a utopia de dias melhores. É o caso da canção Faroeste Caboclo, lançada oficialmente em 1987.

Tal canção em seu título mescla dois termos culturais bastante interessantes. De um lado temos o faroeste, nome dado ao gênero fílmico estadunidense que trata da aventura de conquista e busca (western) do oeste norte-americano. Do outro lado verificamos a presença do elemento étnico brasileiro, o caboclo definindo a mestiçagem de 
branco com índio e sugerindo a opressão de uma raça, surgida em nosso país, principalmente como fruto da opressão européia, no período da colonização.

O percurso traçado aqui é a história de um sujeito marginalizado que se vê obrigado a emigrar de sua região de origem por questão de sobrevivência e que vai sofrer com o determinismo social que o torna oprimido e marginalizado onde quer que estivesse no país, seja em virtude da "cor", da "classe" e/ou devido à origem. Neste sentido é que notamos a metáfora do anti-heró $i$ brasileiro mediante o símbolo de Jesus Cristo de Nazaré. Isto ocorre quando João do Santo Cristo vai ser ao mesmo tempo "vítima" da história e sofrer sua própria via-crúcis, por ser negro, pobre e nascido no campo, bem como ser um grande homem. Isto porque teve um ideário nobre que foi o de querer pedir ao presidente que ajudasse seu povo sofredor.

Renato Russo, a partir da canção Faroeste Caboclo revela o que Boff (2000) na obra A voz do arco-íris chamou de "opção política pelo negro", já que se aproxima da realidade do negro oprimido, como faz a Teologia da Libertação que defende o direito de suas lutas, através de uma crítica à forma como se lida com esse e outros oprimidos da sociedade contemporânea.

Partindo agora mais especificamente do percurso da letra, vemos um ponto importante na personalidade de João que foi a busca incessante de viver "o ódio que Jesus lhe deu". Tal ódio aqui vai ser sinônimo de força para restituir o que a sociedade e seus sistemas lhe haviam tirado, a exemplo do pai, morto por um policial, também uma vida digna e, sobretudo, o respeito à sua classe e cor. O desencontro do sujeito na canção - "Ali não era o seu lugar" - não era à toa, portanto.

Interessante notar como sua busca de realização é sintomática dos sujeitos oprimidos. Oriundo que é do interior da Bahia, João do Santo Cristo busca a cidade de Salvador, alusão interessante à própria figura de Jesus Cristo. Mas a verdade é que será João quem vai acabar salvando o boiadeiro que estava na rodoviária e, a partir de quem, João acaba indo para a região onde as decisões determinantes para os humildes são tomadas, ou seja, em Brasília. Nesta cidade será onde João acabará vivendo a maior complicação de sua existência; será lá onde criará seu plano santo e será simbolicamente crucificado: uma verdadeira Nova Jerusalém.

O que diferencia João do Santo Cristo aqui da figura de Jesus é o fato de ele ter sido marginalizado socialmente como acontece normal- 
mente na nossa sociedade, isto é, não por vontade, mas pela força da opressão política. No contexto da canção, João é influenciado a começar a roubar, mas acaba tornando-se vítima, pois é preso, violentado e estuprado, na prisão, o que só reforça seu caráter de sujeito oprimido.

Além disso, é possível encontrar vários momentos de empatia do sujeito narrador com João, uma vez que são destacados seus elementos humanos sensíveis como: o arrependimento dos pecados motivados pelo amor que começa a sentir por Maria Lúcia (Maria iluminada), a vontade de ter um filho e a volta ao trabalho humilde. Acerca desta personagem, vale dizer o que sugerem Angélica Castilho e Erica Schlude em um livro que aborda criticamente as letras de Renato Russo, chamado "Depois do fim". Para elas, Maria Lúcia pode significar, ao mesmo tempo, a

mãe de Cristo, representada como figura acolhedora, enquanto Lúcia é a luz, também remetendo a Lúcifer. Maria Lúcia funde as duas naturezas: uma luz que desgraça e, ao mesmo tempo, salva. Dessa forma, a figura amada sintetiza o amor que salva e o amor que mata. (Castilho \& Schlude, 2002, p.94)

Sendo assim, João deve parte do seu percurso heróico e digno à presença feminina, fato também semelhante no Jesus Cristo que revelou bastante apreço pelas mulheres. Contudo, embora o surgimento de Maria Lúcia fizesse João querer voltar a ser o melhor de si - volta a ser carpinteiro assim como fora Jesus e seu pai - acaba também tendo aquele caráter negativo que indicam Castilho \& Schlude: gera o sentimento negativo de vingança no momento em que ela o trai. Em seu percurso, assim como Jesus, João também ainda sofre a tentação demoníaca aqui representada pelo homem rico, que the oferece dinheiro para que João realizasse um atentado fatal responsável pela morte de crianças sujeitos, como sabemos, também fortemente protegidos pelo Jesus histórico.

Outro elemento interessante nesta canção é o destino. Assim como Jesus, João se dá conta de qual é seu futuro, pois acabará tendo de "sofrer as conseqüências como um cão". Aludamos a outro aspecto representativo de seu sofrimento. Tratamos do conflito gerado pela traição da amada de João e o duelo que terá com Jeremias, aqui visto como ente representativo do mal. Embora fosse do "bem", João do Santo Cristo acaba morrendo e o conflito é resolvido da seguinte for- 
ma: João acaba matando também seu assassino, Jeremias, por meio da interseção de Maria Lúcia, a quem acaba perdoando no final.

O fim de João é enfatizado pela indiferença e "sensacionalização" por parte da mídia e da burguesia. Normalmente é assim que terminam os oprimidos no contexto brasileiro. Trata-se de uma das várias viacrúcis contemporâneas por que passam tantos oprimidos no Brasil que muitas vezes não têm a quem recorrer e que acabam tornando-se motivo de aplausos pelo seu sofrimento espetacularizado, como constatamos na frase do narrador: "- Se a via-crúcis virou circo, estou aqui."

Por fim, a santidade de João é atestada pelo narrador em virtude da morte de João, ao mesmo tempo herói e santo, como também foi Jesus, sobretudo também porque ambos queriam - mas apenas Jesus conseguiu - "Salvar", "Libertar" o povo que tanto sofre e que muitas vezes dependem tão-somente das ações de políticos para poder sobreviver dignamente.

Contrapondo-se as figuras de Jesus Cristo e João do Santo Cristo, podemos notar o seguinte. De um lado, temos Jesus, traído por dois de seus apóstolos, ou seja, Judas e Pedro, que agiu em prol do outro, curando leprosos, paralíticos e possessos, sacrificando mesmo sua vida pelos seres humanos e que acabou sendo marginalizado por não cumprir a lei judaica da época. Por outro lado, temos João do Santo Cristo, um sujeito marginalizado e oprimido pela sociedade por ser negro e por acabar tornando-se contrabandista de drogas. Um verdadeiro antiherói que, embora fugindo da lei, era ético, queria o bem comum da sociedade e que, assim como Jesus, acabou sendo traído por uma pessoa estimada e, a quem perdoou no final. Seja Jesus ou João do Santo Cristo, ambos entregaram sua vida em busca de uma utopia, realizada apenas no contexto de Jesus que ressuscitou; porém João, que é "do" Santo Cristo, ou seja, da posse de Jesus que também o protege, contribuiu também para a reflexão e combate à opressão aos pobres, assim como reza a Teologia da Libertação.

\section{5. Últimas palavras}

Ambas as obras aqui analisadas, de autores de estilos tão diferentes e de certa forma não-contemporâneos, puderam ser correlacionados sintomaticamente a princípios da Teologia da Libertação.

Seja pela crítica e reconhecimento da figura do Menino Jesus como um ser humano oprimido e carente de auxílio, seja na visão do 
indivíduo que tem objetivos nobres para auxiliar os oprimidos e que acaba sendo marginalizado por isso, ambas as canções apresentam riqueza literária e uma profundidade crítica e teológica, ao mesmo tempo, o que lhes garante sem dúvida a inserção e atualidade dos estudos teológico-literários na Academia e a confluência com a Teologia da Libertação. Essa corrente teológica, embora tenha surgido há muito tempo, parece estar sendo menos empregada pelos teólogos contemporâneos. Mais ela ainda alimenta a utopia de muitos líderes religiosos ou leigos que vêem no Jesus e em sua ressurreição um alento para os diversos flagelados e oprimidos na nossa sociedade, hoje em dia infelizmente mais numerosos e com características ainda mais complexas. 


\section{Referências}

BARCELLOS, José Carlos. Literatura e espiritualidade: uma leitura de Jeunes Années, de Julien Green. Bauru, EDUSC, 2001. (p.55-77) BOFF, Leonardo. Do lugar do pobre. 3.ed. Petrópolis: Vozes, 1986. . A voz do arco-íris. Brasília: Letraviva, 2000.

BOFF, Clodovis \& BOFF, Leonardo. Como fazer Teologia da Libertação. 8.ed. Petrópolis: Vozes, 2001.

BRITO, Fausto \& FREIRE, Roberto. Utopia e paixão: a política do cotidiano. 6.ed. Rio de Janeiro: Racco, 1987.

CASTILHO, Angélica \& SCHLUDE, Erica. Depois do fim - vida, amor e morte nas canções da Legião Urbana. Rio de Janeiro: Hama, 2002.

CONE, James H. O Deus dos oprimidos. Tradução Josué Xavier. São Paulo: Paulinas, 1985.

ECHEGARAY, Hugo. O projeto de Jesus. In: A prática de Jesus. Tradução de Ephraim Ferreira Alves. Petrópolis: Vozes, 1991. p.111-159.

MARASCHIN, J. C. Jesus Cristo na música popular brasileira. In: BOFF, Leonardo et alli. Quem é Jesus Cristo no Brasil? São Paulo: Aste, 1974. (p.97-111).

ROSSI, Luiz Alexandre Solano. Horizontes utópicos e projetos históricos - a centralidade religiosa do messianismo no ordenamento do mundo moderno. São Bernardo do Campo: UMESP, 1999. (Tese de Doutorado)

SOBRINO, Jon. A história de Jesus de Nazaré. 2.ed. Petrópolis: Vozes, 1996. (Col. Teologia e libertação.)

SUNG, Jung Mo. Sujeitos e sociedades complexas: para repensar os horizontes utópicos. Petrópolis: Vozes, 2002. 
ZIOLKOWSKI, Theodore. Fictional transfigurations of Jesus. Princeton University Press, 1978, pp. 34-36.

Links consultados com acesso entre maio e julho de 2008:

Bella Itália - Letras de Músicas: $\underline{\text { http://www.italianoar.com }}$

Censura de músicas na ditadura brasileira: www.censuramusical. com

Gazeta do Povo http://portal.rpc.com.br/gazetadopovo/blog/ $\underline{\text { sobretudo/?id }=674790}$ Academia Brasileira de Letras: $\underline{\text { http://www.academia.org.br }}$ 